\title{
Negative Equity and Foreclosure: Theory and Evidence
}

\section{Christopher L. Foote, Kristopher Gerardi, and Paul S. Willen}

\begin{abstract}
:
Millions of Americans have negative housing equity, meaning that the outstanding balance on their mortgage exceeds their home's current market value. Our data show that the overwhelming majority of these households will not lose their homes. Our finding is consistent with historical evidence: we examine more than 100,000 homeowners in Massachusetts who had negative equity during the early 1990s and find that fewer than 10 percent of these owners eventually lost their home to foreclosure. This result is also, contrary to popular belief, completely consistent with economic theory, which predicts that from the borrower's perspective, negative equity is a necessary but not a sufficient condition for foreclosure. Our findings imply that lenders and policymakers face a serious information problem in trying to help borrowers with negative equity, because it is difficult to determine which borrowers actually require help in order to prevent the loss of their homes to foreclosure.
\end{abstract}

JEL Classifications: D11, D12, G21, R20

Christopher L. Foote and Paul S. Willen are senior economists and policy advisors and Kristopher Gerardi is a research associate at the Federal Reserve Bank of Boston. Gerardi will join the Federal Reserve Bank of Atlanta in September as a research economist. Their email addresses are chris.foote@bos.frb.org, paul.willen@bos.frb.org, and kristopher.gerardi@bos.frb.org respectively.

We thank Tim Warren and Alan Pasnik of The Warren Group, and Dick Howe Jr., the Register of Deeds of North Middlesex County, Massachusetts, for providing us with data, advice, and insight. We also thank Elizabeth Murry for providing helpful comments and edits.

This paper, which may be revised, is available on the web site of the Federal Reserve Bank of Boston at http://www.bos.frb.org/economic/ppdp/2008/ppdp0803.htm.

The views expressed in this paper are solely those of the authors and not necessarily those of the Federal Reserve Bank of Boston or the Federal Reserve System.

This version: June 5, 2008 


\section{Introduction}

As a consequence of the recent nationwide fall in house prices, many American families owe more on their home mortgages than their houses are worth - a situation known as "negative equity." The effect of negative equity on the national foreclosure rate is of obvious interest to policymakers, but this effect is difficult to study with datasets that are commonly used in housing research. In this paper, we exploit unique data from the Massachusetts housing market to make three points. First, during a specific historical episode involving a downturn in housing prices-Massachusetts during the early 1990s - less than 10 percent of a group of homeowners likely to have had negative equity eventually defaulted on their mortgages. Thus, current fears that a large majority of today's homeowners in negative equity positions will soon "walk away" from their mortgages are probably exaggerated. Second, we show that this failure to default en masse is entirely consistent with economic theory. The failure does not need to be explained by factors such as sentimental attachment to homes, moving costs, or the stigma attached to mortgage default. Third, we show that our empirical and theoretical findings have important implications for current proposals designed to address the negative-equity issue and prevent foreclosures. These implications hinge on the incentive problems that arise when lenders cannot distinguish which homeowners with negative equity need help to avoid foreclosure and which ones do not.

Previous analyses of negative equity has been hindered by the lack of data on the complete ownership experiences of individual homeowners. We use data from Massachusetts Registry of Deeds offices that allow us to track every residential mortgage origination and house purchase in Massachusetts starting in January 1987. Because we observe the price of each home purchased, the size of all purchase loans, and the subsequent behavior of housing prices, we are able to construct a rough proxy of housing equity for each Massachusetts homeowner who purchased a home on or after January 1987. The deeds data also allow us to track the eventual outcome of each homeowner. Specifically, we can tell whether any particular homeowner eventually defaulted and experienced a foreclosure. The specific group of borrowers we study in this paper is the set of all post-1986 purchasers who were likely to have had negative equity in 1991:Q4, a time that we believe is comparable to the current situation in the housing cycle. ${ }^{1}$ We find that of the 100,300 borrowers we identify as having negative equity in 1991:Q4, only 6,450 actually lost their homes to foreclosure over the next 3

\footnotetext{
${ }^{1}$ In both 1991 and 2007, house prices had fallen during the previous two years. Furthermore, after 1991, prices continued falling for another two years, which is consistent with some current forecasts as of May 2008.
} 
years. The Massachusetts data also allow us to estimate the incidence of future mortgage defaults. Specifically, we can identify 94,600 borrowers with negative housing equity in 2007:Q4. Using an econometric model of foreclosures estimated using the Massachusetts data, we predict that between 6,500 and 7,600 of these borrowers will lose their homes to foreclosure by the end of 2010. This prediction assumes no policy changes that would modify loan terms, either temporary, or permanently, but it does depend on various macroeconomic conditions and house price outcomes.

To some, the fact that so few borrowers with negative equity actually default will sound odd. Why would borrowers continue to make payments on houses that are worth less than their mortgages? In reality, there typically are good economic reasons for doing so. From a borrower's perspective, the decision to default hinges on how onerous the monthly mortgage payment is, relative to the possibility that the house's value will eventually exceed the balance on the mortgage. Some borrowers with negative equity have little liquid wealth and/or high expenses. For these borrowers, the decision often tilts toward default as the economically rational outcome. But borrowers with negative equity that have ample liquid wealth will usually find it in their economic interest to stay in their homes.

Understanding these theoretical and practical impacts upon the foreclosure decision helps us understand the true role negative equity plays in the borrower's choice of whether or not to default. A foreclosure requires both negative equity and a householdlevel cash-flow problem that makes the monthly mortgage payment unaffordable to the borrower. Cash-flow problems without widespread negative equity do not cause foreclosure waves. ${ }^{2}$ Even if borrowers are having trouble making payments, they will always prefer to sell their homes rather than default, as long as equity in their homes is positive so they can pay off their outstanding mortgage balances with the proceeds of the sales. Similarly, widespread negative equity will not result in a foreclosure boom in the absence of cash-flow problems. Borrowers with negative equity and a stable stream of income will, in most cases, prefer to continue making mortgage payments. Thus, we argue that negative equity does play a key role in the prevalence of foreclosures, but not because (as is commonly assumed) it is optimal for borrowers with negative equity to walk away from affordable mortgages.

These findings have important implications for how lenders address widespread negative equity among their borrowers. Lenders often attempt to mitigate foreclosurerelated losses by extending assistance to borrowers, but in doing so, they face an incomplete information problem. ${ }^{3}$ To lenders, the cost of an assistance policy depends

\footnotetext{
${ }^{2}$ The 2001 U.S. recession is a good example.

${ }^{3}$ In the remainder of this paper we refer to the party that is entitled to the interest and principal
} 
on how many borrowers qualify for assistance (that is, how many borrowers are currently in a position of negative equity). The benefits of an assistance policy depends, in part, on the fraction of borrowers that truly need assistance (that is, how many borrowers with negative equity will default if no assistance is given). Our empirical and theoretical results imply that the number of borrowers who would qualify for an assistance policy can be far greater than the number of borrowers who truly need help. In other words, the costs of forgone income from borrowers who would have made payments often exceeds the benefits of fewer foreclosures.

We apply these lessons to two common loss-mitigation strategies sometimes offered by lenders. The first strategy is "loan modification," in which the terms of the loan (such as the outstanding balance, or the interest rate) are permanently adjusted to the advantage of the borrower. The second policy is "forbearance," in which the borrower receives only a temporary reduction of the monthly mortgage payment, with the stipulation that this benefit is repaid, with interest, at a later date. We show that the incomplete information problem discussed above is particularly severe for loanmodification policies, because these plans are attractive to virtually all borrowers, not just those who are in danger of foreclosure. In contrast, borrowers who do not need help are unlikely to find forbearance attractive, because this policy alters only the timing of repayment, not how much is owed. Because forbearance does not suffer from the same moral hazard problem as loan modification, the costs of a forbearance policy turn out to be significantly lower. ${ }^{4}$

\section{Homeowners with negative equity}

We use a unique historical dataset of mortgages and house values in Massachusetts, encompassing two housing downturns, to identify and track borrowers who are likely to be in positions of negative equity. We first study the experiences of borrowers with negative equity during the state's previous housing downturn in the early 1990s. We

payments of the mortgage the "lender." Thus, this term refers to both a mortgage lender that keeps loans in its own portfolio, as well as an investor in mortgage-backed securities (MBS).

${ }^{4}$ In addition, a forbearance policy may be much more appealing from an institutional standpoint, as forbearance does not violate any of the rules of the mortgage backed security (MBS) agreements, and thus servicers are able to implement such a policy at their own discretion. Modifications, on the other hand, alter the terms of mortgage contracts, and thus may violate the terms of MBS agreements in certain cases. The institutional frictions that may hinder certain loss-mitigation policies are beyond the scope of this paper. However, our conversations with industry experts suggest that they may play a very important role in the ultimate success or failure of many foreclosure prevention policies, and thus are an important topic for future research. 
then use a duration model estimated on Massachusetts data to predict the eventual foreclosures of borrowers with negative equity as of 2007:Q4.

\subsection{Massachusetts Registry of Deeds data}

In this section we briefly describe the data and the model that we use for our foreclosure and negative equity calculations. For further details, we direct the reader to Gerardi, Shapiro, and Willen (2007), hereafter referred to as GSW.

We use data purchased from the Warren Group that come from Massachusetts county-level, Registry of Deeds offices. These data include information on virtually all residential mortgage and housing transactions, including foreclosure deeds, registered in the state over the past 20 years. The Warren Group has also calculated a set of property identifiers in the data that allow us to track the same residential property over time. Using this information, we are able to identify consecutive purchase deeds on the same house, and all of the mortgages originated in the time-span between the deeds. We call this time-span an "ownership experience," as it corresponds to the period during which a household occupies a particular home. The data include the dates and nominal amounts of housing purchases and sales, as well as mortgage originations. Thus, we are able to calculate a precise loan-to-value (LTV) ratio at the time of purchase [for each borrower in the data]. These LTV ratios are cumulative in the sense that these include all mortgages taken out at the time of purchase, including "piggyback" or second (and even third) mortgages.

We also use the data to construct house price series. Specifically, the ability to identify consecutive purchase deeds for the same property allows us to calculate house price indexes at a fairly disaggregated level using the Case-Shiller repeat-sales methodology. We are able to calculate more than 100 house price indexes for the 350 towns and cities in Massachusetts. ${ }^{5}$

Using these house price indexes and initial LTV ratios, we are able to calculate a negative equity proxy for each borrower in the data. We form an estimate, $E_{i t}$, that corresponds to the amount of equity that borrower $i$ has at time $t$, based on the initial LTV ratio, and the amount of cumulative house price appreciation experienced in the town where the borrower has resided since the date of purchase:

$$
E_{i t}=\left(1-L T V_{i}\right)+C_{j t}^{H P A},
$$

where $C_{j t}^{H P A}$ corresponds to the cumulative amount of house price appreciation experienced in town $j$ from the date of house purchase through time $t$.

\footnotetext{
${ }^{5}$ We are able to calculate price indexes for the larger towns and cities in Massachusetts, but in order to obtain precise indexes, we were forced to combine many of the state's smaller towns.
} 
This equity proxy is a fairly crude measure, because it does not contain information about current mortgage balances (that is, current LTV ratios). Unfortunately, we cannot tell whether a loan is an adjustable-rate mortgage (ARM) or a fixed-rate mortgage (FRM), and we do not observe the initial interest rate associated with each mortgage contract in the data. Thus, we are unable to construct a measure of the current mortgage balance. Furthermore, we do not observe mortgage termination dates, so we cannot measure whether a household has extracted cash in the course of a refinance. The inability to measure the amount of amortization over time for a given mortgage will bias our equity measure upwards, while the inability to measure mortgage equity withdrawal will bias our equity measure downwards. Thus, it is unclear in which direction the overall bias in our equity estimate will run.

In addition to home sales and mortgage transactions, the Warren Group data contain some information regarding foreclosures; we use data that includes foreclosure deeds going back to 1990. A foreclosure deed signifies the very end of the foreclosure process, when a property is sold at auction, either to a private bidder, or to the lender, at which point the property status becomes real-estate owned (REO).

\subsection{Negative equity exercise}

In this section we estimate the percentage of Massachusetts homeowners who are currently in a position of negative equity (as of 2007:Q4) and who will default on their mortgage and experience a foreclosure over the next three years. We believe that this is an important calculation, as it provides an upper bound for the percentage of borrowers whom policymakers can hope to help avoid the foreclosure process.

We break this section into three subsections. In 2.2.1 we discuss the experiences of borrowers with negative equity in the last housing downturn, focusing on 1991:Q4, and also document the number of negative equity borrowers as of 2007:Q4. In 2.2.2 we further explore some of the details of the empirical model that we use to forecast future foreclosures. Finally, in 2.2.3 we present the results of our foreclosure simulations.

\subsubsection{Borrowers with negative equity in 1991 and 2007}

Massachusetts experienced a significant housing downturn in the early 1990s that coincided with a national recession that was especially severe in New England. This adverse combination resulted in a significant foreclosure boom, depicted in Figure 1, which displays a measure of the foreclosure rate and house prices in Massachusetts 
from 1990 through 2007. ${ }^{6}$ Between the summer of 1988 and the winter of 1993, house prices in Massachusetts fell by 22.7 percent. Foreclosures peaked in 1992 and did not return to their 1990 level until the end of 1999.

Using initial LTV ratios and town-level house price indexes, we calculate the number of Massachusetts mortgage borrowers who were in a position of negative equity in 1991:Q4. ${ }^{7}$ We concentrate on 1991, as we believe that it may be a good comparison year to 2007. Massachusetts foreclosures did not peak until 1992 in the previous housing downturn, and many observers believe that given the current housing downturn, foreclosures both in Massachusetts and the nation will not peak until either 2008 or 2009. The first column in Table 1 contains summary statistics regarding the number of borrowers with negative equity at the end of 1991, and the number of subsequent foreclosures experienced by these borrowers. We find that approximately 100,300 Massachusetts borrowers were in a position of negative equity in 1991:Q4. ${ }^{8}$ Of these borrowers, approximately 6.4 percent (slightly fewer than 6,500 borrowers) ended up in foreclosure over the next three years. This percentage may seem extremely low to many readers, but in Section 3 below, we show that it is consistent with economic theory.

In Table 1, the last column of the second row contains our calculation regarding the number of borrowers with negative equity at the end of 2007. In 2007:Q4, we find that approximately 94,600 Massachusetts borrowers are in a position of negative equity. This is approximately 10 percent of the state's mortgage borrowers. ${ }^{9}$ If we assume that the same percentage of borrowers who were in a negative equity position and defaulted and experienced a foreclosure in the last housing downturn will default

\footnotetext{
${ }^{6}$ The foreclosure rate is calculated as the number of foreclosures on residential homes in a given year, divided by the number of residential parcels in that year. A parcel is defined as a real unit of property used for the assessment of property taxes, and a typical parcel consists of a plot of land defined by a deed and any buildings located on the land. Information on parcel counts is obtained from the Massachusetts Department of Revenue.

${ }^{7}$ Our mortgage and housing transaction data begin in January of 1987, so we limit our calculation to owners who purchased their homes after this date. This should provide very good coverage of borrowers with negative equity in 1991:Q4, as high house price appreciation in the mid-to-late 1980s meant that borrowers who purchased their homes before 1987 were very unlikely to be in a negative equity position at the end of 1991.

${ }^{8}$ We are able to calculate initial LTV ratios, and thus equity positions for 277,470 Massachusetts borrowers in the fourth quarter of 1991. This number is much smaller than the active number of mortgage borrowers during this time period, because we do not have data on purchase deeds before January 1, 1987.

${ }^{9}$ We are able to calculate initial LTV ratios, and thus equity positions for 977,016 Massachusetts borrowers in 2007:Q4. Again, this number captures only mortgage borrowers who purchased homes on or after January 1, 1987.
} 
in this downturn, then we would expect a little more than 6,100 borrowers to default over the next three years. However, applying the percentage from 1991 to borrowers with negative equity in 2007 may be problematic, as there are substantial differences between the borrowers present in mortgage markets in the early 1990s and mortgage borrowers today.

Table 2 displays summary statistics of borrowers with negative equity in 1991 and 2007. It contains information broken down by property type, the zip code's income level (from the 2000 Census), percentage of minority households in the zip code (from the 2000 Census), and whether the borrower purchased the property with a mortgage financed by a subprime lender. In both periods, there are many similarities between borrowers with negative equity. In both 1991 and 2007 a disproportionate number of borrowers with negative equity were located in zip codes with low-tomoderate income (LMI) levels, ${ }^{10}$ and lived in condominiums or multi-family houses. However, an important difference may be the presence of the subprime mortgage market. The subprime market did not exist in 1991, while approximately 19 percent of the 2007 negative equity borrowers purchased their homes with a subprime mortgage, compared to only 4.5 percent of active mortgage borrowers in 2007 . The subprime mortgage market originated a wide variety of loans considered "high risk" because of the characteristics of both the borrower and mortgage contract. ${ }^{11}$ For example, in the data we see many recent subprime borrowers with higher average LTV and debtto-income (DTI) ratios than those common in the $1990 \mathrm{~s}^{12}$ Thus, we may expect a higher percentage of borrowers with negative equity in 2007 to subsequently default on their mortgages, compared with negative equity borrowers in the early 1990s. For this reason, we need a model to forecast the number of negative equity borrowers in 2007 who will experience a foreclosure going forward.

\subsubsection{A duration model of ownership termination}

To forecast the percentage of negative equity borrowers who will experience a future foreclosure, we use the duration model employed in GSW. In this section we briefly describe the main properties of the model.

The policy goal is to model the conditional probability of foreclosure, or hazard function, which is simply the probability that ownership $i$ will experience a foreclosure

\footnotetext{
${ }^{10}$ Low income zip codes are defined to be zip codes in which the median household income is less-than-or-equal to 50 percent percent of the state median, while moderate income zip codes have median income values between 50 percent and 80 percent of the state median.

${ }^{11}$ For a more detailed discussion of the emergence of the subprime mortgage market see Pennington-Cross (2002) and Chomsisengphet and Pennington-Cross (2006).

${ }^{12}$ For details, see Figure 9 in Foote, Gerardi, Goette, and Willen (2008).
} 
at time $t$, conditional on having lived in the house through time $t-1$. In our chosen specification, there are two hazard functions corresponding to the two competing actions that the borrower can take to end the ownership experience: foreclosure and sale.

We use a proportional hazard specification, which assumes that there is a hazard common to all homeownership experiences, and that the covariates, or explanatory variables, have proportional effects on these common hazards. ${ }^{13}$

The covariates we use are almost the same as those employed in GSW. These include a measure of the borrower's equity in the home, which is a linear combination of the initial LTV ratio and cumulative house price appreciation since the time of purchase [equation (1)], unemployment rates at the town level from the Bureau of Labor Statistics (BLS), the contemporaneous six-month LIBOR, ${ }^{14}$ median household income and the percentage of minority households from the 2000 Census at the zip code level, an indicator variable that helps identify whether the borrower financed the purchase with a mortgage from a subprime lender, ${ }^{15}$ and indicator variables for multi-family homes and condominiums. Finally, we also include an indicator variable that identifies when a borrower is in a position of negative equity. As discussed above, the equity calculation does not take into account amortization of the mortgage, or refinancing activity. When the equity position of the household falls below zero, as a result of house price depreciation, the negative equity indicator takes on a value of one.

\subsubsection{Results from the model}

Using the duration model, we can forecast the number of foreclosures that these negative equity borrowers will experience over the period 2008-2010. To do this, we estimate the model using the entire span of our data (1989-2007), take the parameter estimates, and use these to form predicted foreclosure probabilities over the next three years for each negative equity borrower. Table 3 displays the parameter estimates. The first column displays estimates corresponding to the default parameters, while the second column displays estimates corresponding to the sale parameters. The direction

\footnotetext{
${ }^{13}$ See the Appendix for a more technical discussion of the model and the proportional hazard framework.

${ }^{14}$ LIBOR stands for the London Interbank Offered Rate, and is determined by rates that banks participating in the London money market offer each other for short-term deposits. It is often used as a benchmark interest rate in the mortgage market.

${ }^{15}$ We use the HUD subprime lender list to identify mortgages in the data that were obtained from a subprime lender, and take this as our subprime mortgage definition. For a detailed discussion and robustness check of this subprime definition, we direct the reader to GSW.
} 
of the signs of the coefficient estimates for default are consistent with our expectations, and with evidence from prior studies. The estimated effects of the short-term interest rates (LIBOR), and the unemployment rate on the default decision are positive. Borrowers who finance their house purchase with a mortgage from a subprime lender are more likely to default than those who use a prime lender. Borrowers who purchase a condominium or a multi-family property are more likely to default than borrowers who purchase a single-family home. Finally, a decrease in housing equity is estimated to have a positive effect on the probability of default, while a decrease in housing values that results in a position of negative equity is estimated to have an even larger positive effect on foreclosure incidence, although this effect is not statistically significantly different from zero.

Since we assume a proportional hazard functional form, the magnitude of each estimate in Table 3 is interpreted as a semi-elasticity, or the proportional increase in the overall hazard rate due to a unit increase in each covariate. In the top panel of Table 4 we display the "standardized elasticities," which correspond to the percentage changes in the conditional hazard due to a one-standard deviation change in each continuous explanatory variable, and a change from zero to one for each dichotomous explanatory variable. In the bottom panel of Table 4, we display the effects of these changes on the level of the conditional default hazard for ownerships that have aged five years. ${ }^{16}$

Given these parameter estimates, for each quarter, we take the individual predicted default probabilities and aggregate these to obtain the number of expected foreclosures for the negative equity borrowers, where the expectation is taken in 2007:Q4. ${ }^{17}$ In order to do this, we need forecasts for the time-varying covariates in our model, which include unemployment rates, the six-month LIBOR, and house price appreciation.

\footnotetext{
${ }^{16}$ The proportional hazard assumption can be seen in the last row of the bottom panel in Table 4 , which displays the effect on the default hazard due to the combination of a subprime purchase mortgage and a one-standard-deviation fall in negative housing equity. The change in the default hazard is dramatic, increasing from approximately 0.05 percent to almost 1.5 percent. The intuition for this huge effect comes from the proportional hazard assumption. The fall in equity increases the default hazard by approximately 220 percent, from 0.05 percent to 0.16 percent. The difference between a subprime purchase mortgage and a prime purchase mortgage then increases the default hazard by 813 percent, from 0.16 to 1.5 percent.

${ }^{17}$ The expected number of foreclosures is given by the following expression,

$$
E_{0}\left[\text { foreclosures }_{t}\right]=\sum_{i} \widehat{\lambda_{i t}},
$$

where $\widehat{\lambda_{i t}}$ corresponds to the predicted foreclosure probability of borrower $i$ in quarter $t$.
} 
Since forecasts of house prices are notoriously unreliable, we consider a few different house price appreciation scenarios. In the first scenario, we assume that house prices will remain flat over the next three years. In the second scenario, we assume that house prices will decline by 10 percent over the next three years, at a steady rate. Since many observers of the U.S. housing market are calling for further price declines in most regions of the country, we think that this is not an unreasonable assumption. Finally, in the third scenario,, we assume that house prices will first decline substantially and bottom out after one year, and then increase over the following two years. Specifically, we assume that house prices will fall by 5 percent over the first year, and then increase by 1 percent and 3 percent in the following two years, respectively. Figure 2 displays the path of house prices under our three different scenarios. In all of the scenarios, we assume that the unemployment rate and six-month LIBOR remain constant at their 2007:Q4 levels.

Results for the three different scenarios are displayed in Table 1 columns (2) through (4). For the first scenario, the duration model predicts that about 6.9 percent (6,500 households) of the borrowers with negative equity in 2007:Q4 will experience a foreclosure over the next three years. In the second scenario, the model predicts that approximately 8.0 percent of borrowers with negative equity will default, which corresponds to approximately 7,600 borrowers. Finally in the third scenario, the model predicts that about 7.5 percent $(7,050$ households) of the borrowers with negative equity will default on their mortgages. It is evident from these results that more severe house price declines translate into more defaults among borrowers with negative equity, according to the model. For example, comparing the second and third scenarios, we see that for the third scenario, the model predicts more foreclosures in the first year, but for the second scenario, it predicts higher foreclosure numbers in the second and third years. This pattern occurs for the third scenario because we have assumed a steeper decline in house prices during the first year, followed by positive appreciation in the second and third years, compared with continued negative appreciation for the second scenario.

These percentages are comparable to the actual 1991 percentage of Massachusetts borrowers with negative equity who went on to experience a foreclosure, although these predictions for 2008-2010 are slightly higher. The results of this exercise imply a range of values between 6 and 8 percent for the percentage of negative equity borrowers that default and experience foreclosure. Another way of stating this observation is that the percentage of negative equity borrowers who do not default, but continue to pay off their mortgages, is more than 90 percent. $^{18}$

\footnotetext{
${ }^{18}$ Table 5 contains the model's foreclosure predictions for all mortgage borrowers under the same
} 


\section{The basic economics of default from the bor- rower's perspective}

Economic theory poses one categorical prediction about the relationship between negative equity and default, which is that negative equity is a necessary condition for default. In other words, if a borrower is not in a position of negative equity, then he/she should never default. This conclusion follows simply from the fact that positive equity implies that a borrower can sell the house, pay off the mortgage, and keep the difference, a better outcome under any circumstance compared with stopping payment on the mortgage and leaving the home. What economic theory does not say is that if a borrower has negative equity, he/she should always default. In the language of logic, negative equity is not a sufficient condition for default.

The idea that one should continue making monthly mortgage payments even when the market value of the house is worth less than the outstanding balance on the mortgage seems puzzling to many people. Some commentators view the fact that most people with negative equity keep their homes as a "failure" of the theory, and attribute the decision to keep servicing the mortgage to the owner's sentimental attachment to the home, inertia, moving costs, reputational issues, or default penalties that may adversely affect access to future credit. In the financial economics literature the combined effect of these factors has been termed "transactions costs." 19 While we acknowledge that many, if not all, of these factors influence the borrower's default decision, our point illustrated in a very simple framework below, is that these are not necessary to explain why the majority of borrowers with negative equity do not default on their mortgages. ${ }^{20}$

We develop a simple framework to illustrate the factors that determine a borrower's decision to default or to continue making mortgage payments. We assume a two-period world $(t=1,2)$, with two possible future states, good and bad. The good state occurs with probability $\frac{3}{4}$, while the bad state occurs with probability $\frac{1}{4}$. We assume that the borrower has purchased a home valued at $P_{1}$ in the first period, with a nominal mortgage balance of $M_{1}$ in the first period, where $M_{1}<P_{1}$. In the first period, the borrower decides between making the mortgage payment and staying in the home, or stopping payment and defaulting. We assume that the borrower either sells the home in the second period or defaults on the mortgage. If the good

three house price scenarios discussed above. Foreclosures are predicted to be highest for the scenario in which house prices decline by 10 percent total, at a steady rate over three years.

${ }^{19}$ Stanton (1995) was the first study to incorporate transactions costs into a model of mortgage termination.

${ }^{20} \mathrm{Kau}$, Keenan, and Kim (1994) make this point in the context of an option-theoretic model. 
state occurs, the price of the house in the second period is given by $P_{2}^{G}$, while if the bad state occurs, the price is given by $P_{2}^{B}$. For illustrative purposes, we assume that $P_{2}^{B}<M_{2}$, where $M_{2}$ is the remaining nominal mortgage balance in the second period. The value of the house to the borrower, or the benefit of staying in the home, in the first period, $t=1$, is given by,

$$
V_{1}^{H}=\operatorname{rent}_{1}+\frac{1}{1+r} \cdot\left[\frac{3}{4} P_{2}^{G}+\frac{1}{4} P_{2}^{B}\right]
$$

where $r^{2} t_{1}$ is the value of housing services that the borrower obtains from the home in the first period. Since the house allows the borrower to live rent free, the saved rental payment is a component of the value of the house and the benefit of staying in the home. The second component of the house value is the expected present discounted market value of the house in the second period, since we assume that the household will sell the home in the final period. This value is given by a weighted average of the price that occurs in the good state, $P_{2}^{G}$, and the price that occurs in the bad state, $P_{2}^{B}$, where the weights are given by the probabilities that each state occurs. We assume that the borrower discounts future payoffs by the quantity $\frac{1}{1+r}$. The cost to the borrower of staying in the home, or the value of the mortgage, is given by,

$$
V_{1}^{M}=\operatorname{mpay}_{1}+\frac{1}{1+r} \cdot\left[\frac{3}{4} M_{2}+\frac{1}{4} P_{2}^{B}\right]
$$

where mpay $_{1}$ is the first-period mortgage payment that the borrower is required to make, and $M_{2}$ is the remaining mortgage balance in period 2, which the borrower is required to repay. Note that in equation 4 we have included the price of the house in the bad state, $P_{2}^{B}$, as a substitute for the value of the mortgage in the bad state, $M_{2}$. Since the borrower has the option to default on the mortgage in the second period as well as in the first period, in which case he/she essentially sells the home back to the seller for the outstanding balance on the mortgage, the value of the mortgage in the second period, $M_{2}$, is never greater than $P_{2}$. Since we assume that $P_{2}^{B}<M_{2}$ and $P_{2}^{G}>M_{2}$, if the bad state transpires, then the borrower defaults, while if the good state occurs, the borrower sells the home, which explains the form of the second term in equation $4 .^{21}$

In deciding whether or not to default on the mortgage, the borrower compares the benefit of staying in the home to the cost of doing so. If the benefit is larger than the cost, $V_{1}^{H} \geq V_{1}^{M}$, then the borrower continues making mortgage payments, and keeps the house. ${ }^{22}$ In contrast, if the cost is larger than the benefit, $V_{1}^{H}<V_{1}^{M}$,

\footnotetext{
${ }^{21}$ In other words, this term captures the value of the future default option.

${ }^{22}$ We assume for simplicity that if the benefit is exactly equal to the cost, then the borrower stays in the home and does not default.
} 
then the borrower stops making payments, and defaults on the mortgage. Thus, from the borrower's perspective, the default decision depends on the sign of the following expression, where we subtract (4) from (3):

$$
V_{1}^{H}-V_{1}^{M}=\left(\text { rent }_{1}-\text { mpay }_{1}\right)+\frac{1}{1+r} \cdot\left[\frac{3}{4} P_{2}^{G}-\frac{3}{4} M_{2}\right] .
$$

It is important to notice that the outstanding balance of the mortgage in the first period, $M_{1}$, and the market price of the home in the first period, $P_{1}$, do not appear in equation 5. This is because neither accurately measures the benefits and costs of keeping the house and not defaulting on the mortgage. Equation 5 implies that borrowers with similar homes (with respect to both price and location) and similar mortgage terms will exhibit identical behavior when it comes to making default decisions. However, the empirical literature has shown that, even when conditioning on observable mortgage characteristics and property characteristics, there is substantial heterogeneity in default behavior across borrowers. ${ }^{23}$

A common explanation of this finding, advocated in the literature (see Stanton, 1995, for example), is that significant transactions costs are associated with defaulting, and these transactions costs differ across borrowers. As discussed above, these costs may include moving costs, default penalties that take the form of limited future access to credit markets, sentimental attachment to the home, or even the presence of moral qualms associated with defaulting on one's debts. We can easily capture the combined effect of all of these factors by adding to equation 5 a single term that we call Stigma $a_{i}$ :

$$
V_{1}^{H}-V_{1}^{M}+\text { Stigma }_{i}=\left(\text { rent }_{1}-\text { mpay }_{1}\right)+\frac{1}{1+r} \cdot\left[\frac{3}{4} P_{2}^{G}-\frac{3}{4} M_{2}\right]+\text { Stigma }_{i} .
$$

Thus, if Stigma $_{i}>0$, then a borrower for whom $V_{1}^{H}<V_{1}^{M}$ may not default. To the extent that Stigma $_{i}$ differs across borrowers, default behavior will differ across households.

While transactions costs of the variety discussed above are likely to play an important role in default behavior at the individual level, these considerations are unlikely to provide a complete explanation for the amount of heterogeneity in individual default decisions. This is because factors such as individual household-level income shocks (especially unemployment), health shocks, and other family-level shocks (death or divorce) have been shown to be important determinants of foreclosure incidence. If transactions costs were in fact the main source of individual heterogeneity in default

\footnotetext{
${ }^{23}$ For a review of the early empirical mortgage default literature see Quercia and Stegman (1992). Vandell (1995) reviews the empirical studies that have tested the frictionless, option-theoretic models of default, which predict that borrowers with similar mortgages and homes will exhibit identical default behavior.
} 
behavior, then we would expect a strong correlation between these individual-level shocks and transactions costs. While data are not available to formally test this hypothesis, it is difficult to come up with a theoretical rationale for why this would be the case.

In GSW, the authors argue that depending on their income prospects, financial situation, and other factors, borrowers discount the future differently. One way to think of this is to compare a borrower who has credit card debt with a borrower who has only riskless savings. The relevant cost of funds for the former is the credit card interest rate, say, 20 percent, and for the latter is the return on riskless savings, 5 percent. $^{24}$ The cost of funds is the relevant rate at which borrowers discount future consumption and thus payoffs, since it is the rate at which a borrower is willing to sacrifice future consumption for current consumption. Thus, this explanation relies on heterogeneity in the rates by which households discount future payoffs, $r$. We can see this by modifying equation 6 so that the discount factor is indexed by $i$.

$$
V_{1}^{H}-V_{1}^{M}+\text { Stigma }_{i} \equiv\left(\text { rent }_{1}-\text { mpay }_{1}\right)+\left(\frac{1}{1+r_{i}}\right) \cdot\left[\frac{3}{4} P_{2}^{G}-\frac{3}{4} M_{2}\right]+\text { Stigma }_{i} .
$$

Why should differences in $r_{i}$ across borrowers be correlated with the individual-level shocks discussed above? Or, in other words, what accounts for differences in the costs of funds, and why should these differences be connected to individual-level shocks? Borrowers in financial distress are much more likely to borrow at high interest rates. Thus, the cost of funds provides a channel for the link between employment shocks, medical shocks, and even family-level shocks, such as divorce, and the incidence of foreclosure. From equation 7, we see that, ceteris paribus, borrowers with higher $r_{i} \mathrm{~s}$ are characterized by lower values of $V_{1}^{H}-V_{1}^{M}+S t i g m a_{i}$, and thus, are more likely to default.

To summarize, in this section we have shown that negative equity does not automatically lead to foreclosure, even in the absence of moving costs and default penalties. Furthermore, variation in defaults across otherwise similarly situated borrowers need not rely on differences in transactions costs. Rather, variation in financial stability across households, which results in heterogeneity across households in the cost of funds and the rate at which households value future payoffs, can explain variation in foreclosure incidence.

\footnotetext{
${ }^{24}$ The term "cost of funds" refers to the interest rate at which a given household or individual can borrow. For a household with no savings and positive credit card debt, the cost of funds would be their credit card interest rate, since they would need to use their credit card to borrow. However, for a household with substantial savings, the cost of funds would be the savings rate, which is the rate at which the household would borrow from itself.
} 
Many argue that the above logic is flawed because of something akin to an arbitrage opportunity. Why, they propose, in a frictionless world, wouldn't a rational borrower default on the current mortgage, then buy the same house back with a smaller mortgage? The answer is that such a decision would be irrational. We have shown that even with negative equity, defaulting on a mortgage can have negative net present value - the benefits of reduced obligations do not outweigh the costs of reduced income. To see this intuitively, consider a borrower with a million dollar mortgage on a hundred thousand dollar house. How can it make sense to stay? Suppose the borrower has a zero-interest, interest-only mortgage. The fact that it would be impossible to obtain a similar mortgage after default acts to lower the borrower's cost of the mortgage, and makes it worthwhile to keep servicing the mortgage. Obviously, this is an extreme example, but the intuition for the positive interest case is the same.

\section{Lenders, loss mitigation, and incomplete infor- mation}

In this section, we look at the lender's decision to offer loss mitigation options to the

borrower. The key task for the lender is to identify borrowers with negative equity who are truly at risk of foreclosure. If the lender gives loss mitigation to a borrower who is not at risk of foreclosure, then the bank incurs the cost of this action, but obtains no benefit from it, since the borrower would have made the promised payments anyway. The better job a lender can do to accurately identify at-risk borrowers, the more assistance it can profitably offer, and the more foreclosures it can avert.

Consider the following model. The lender has an outstanding loan and the value of that loan, conditional on the borrower not defaulting, is $m$. The house is worth $p_{H}$ and we assume that it costs $\lambda$ dollars to foreclose on the borrower, so the lender recovers $p_{H}-\lambda$ dollars if it chooses to foreclose on the borrower. The probability that the borrower will default on the loan is $\alpha_{0}$.

A loss mitigation plan is comprised of three variables $\left(\alpha_{1}, m^{*}, f\right)$. After loss mitigation, the new value of the loan is $m^{*}$. The difference between $m^{*}$ and $m$ could represent many things, depending on the policy option chosen. For example, if the lender permanently modifies the loan, then $m^{*}$ will typically fall short of $m$ because of lower expected interest payments or a smaller principal balance. If a lender allows the borrower to delay repayment, then the gap between $m$ and $m^{*}$ reflects the time value of money. The loss mitigation plan also affects the amount recovered in foreclosure, 
which changes from $p_{H}-\lambda$ to $f$ in foreclosure, while the probability of foreclosure changes to $\alpha_{1}$, where $\alpha_{1}<\alpha_{0}$. Should the lender adopt $\left(\alpha_{1}, m^{*}, f\right)$ ? To answer this question, the lender compares the expected recovery in the absence of the policy to the expected recovery under the loss mitigation policy. The expected recovery without it is,

$$
E[\text { Recovery }]=\alpha_{0}\left(p_{H}-\lambda\right)+\left(1-\alpha_{0}\right) m
$$

since the borrower repays the mortgage with probability $1-\alpha_{0}$ and defaults with probability $\alpha_{0}$, in which case the lender receives the value of the house less foreclosure costs. With loss mitigation, the lender recovers,

$$
E\left[\text { Recovery }{ }^{*}\right]=\alpha_{1} f+\left(1-\alpha_{1}\right) m^{*} .
$$

If equation (9) exceeds equation (8), then policy $\left(\alpha_{1}, m^{*}, f\right)$ makes sense from a lender's profit-maximizing perspective. If, for expositional reasons, we assume that $f=\left(p_{H}-\lambda\right)$, then the net gain from loss mitigation is:

$$
\text { Net Gain }=\underbrace{\left(\alpha_{0}-\alpha_{1}\right)}_{\begin{array}{c}
\text { Reduction } \\
\text { in } \\
\text { foreclosure } \\
\text { prob. }
\end{array}} \times \underbrace{\left(m-\left(p_{H}-\lambda\right)\right)}_{\begin{array}{c}
\text { Loss given } \\
\text { foreclosure }
\end{array}}-\underbrace{\left(1-\alpha_{1}\right)}_{\begin{array}{c}
\text { Pct. repay } \\
\text { without } \\
\text { plan }
\end{array}} \times \underbrace{\left(m-m^{*}\right)}_{\begin{array}{c}
\text { Reduced } \\
\text { value of } \\
\text { the } \\
\text { mortgage }
\end{array}},
$$

and this gain must be positive for the foreclosure loss mitigation policy to be worthwhile from the lender's perspective.

The first term on the right-hand side is the benefit of loss mitigation: the reduction in the likelihood of foreclosure times the loss that would otherwise be incurred. The second term shows the costs: all the borrowers who would have repaid anyway times the reduction in the value of their mortgages. If we take an extreme example, suppose that $\alpha_{0}=1$, so that all of the borrowers in the pool will default unless we institute a mitigation policy, and $\alpha_{1}=0$, so the policy completely eliminates mortgage default. Then, the lender gains if $m^{*}>\left(p_{H}-\lambda\right)$, that is, so long as the reduced value of the loan exceeds the recovery in foreclosure.

Equation (10) illustrates the limitations of loss mitigation policies. The key problem is that the lender needs to be very accurate in identifying at-risk borrowers. The reason is that the costs of loss mitigation are proportional to $1-\alpha_{1}$, the fraction of the borrowers who take loss mitigation and end up not defaulting. It is easy to see that the lower bound on that proportion is given by $1-\alpha_{0}$, the percentage of borrowers with negative housing equity offered loss mitigation who do not need it, because they were never in danger of foreclosure. If $\alpha_{0}$ is large to begin with, then the costs of loss mitigation will be large. 
Another illustrative example to consider is the case where $\alpha_{1}=0$, but $0<\alpha_{0}<1$. In this case, loss mitigation eliminates default, but the question is how much of a reduction in the value of the mortgage can the lender tolerate? In other words, the gain will be positive if

$$
m-m^{*}<\alpha_{0} \times\left(m-\left(p_{H}-\lambda\right)\right) .
$$

The reduction in the value of the mortgage cannot exceed the loss given foreclosure times the probability of foreclosure associated with the borrower receiving loss mitigation. For example, suppose that we offered loss mitigation to all borrowers with negative equity. According to our estimates from Massachusetts data, $\alpha_{0}<0.10$, so the maximum assistance possible would be less than 10 percent of the expected loss from foreclosure. Thus, even if lenders thought they would lose 50 percent of the value of the mortgage in foreclosure, to avoid losing money, their loss mitigation scheme could reduce the value of the mortgage only by five percent.

To illustrate the importance of accurately identifying at-risk borrowers, we first consider a simple plan in which lenders agree to write down debt for any borrower with negative equity. Using our duration model discussed in Section 2.2.2, we can simulate such a plan, and quantify how successful such a plan could be in preventing foreclosures, under various assumptions about the path of future house prices. To keep things as simple as possible, we take each negative equity borrower in the data in 2007:Q4, and set each equity balance to zero. We then simulate the model under the three scenarios discussed above in Section 2.2.3: flat house prices for three years; a uniform 10 percent decline in house prices over three years; and a 5 percent decline over one year, followed by a 1 percent increase in the second year, and a 3 percent increase in the third year. The results are displayed in Table 6.

As in Table 5, each row of Table 6 displays the number of predicted foreclosures in a given quarter. The last row of the table displays, for each house price scenario, the percentage of negative equity foreclosures prevented by the principal write-down policy. The success rate ranges from approximately 17 percent in the scenario where we assumed that house prices fall steeply and then subsequently increase, to approximately 38 percent in the scenario where we assumed that house prices do not change.

Thus, our calculations show that a principal reduction policy, which eliminated negative equity for all borrowers, would not completely solve the foreclosure problem. Depending on house price appreciation going forward, we estimate that such a policy would prevent 15 to 40 percent of foreclosures on negative equity borrowers. If we make the conservative assumption that $\alpha_{0}=0.10$, then $0.06 \leq \alpha_{1} \leq 0.085$. Now, assuming the best-case scenario $\left(\alpha_{1}=0.06\right)$, equation 10 becomes 


$$
\left(m-m^{*}\right) \frac{\left(1-\alpha_{1}\right)}{\left(\alpha_{0}-\alpha_{1}\right)}=24 \cdot\left(m-m^{*}\right)<m-\left(p_{H}-\lambda\right) .
$$

This implies that the maximum level of assistance for which a policy makes financial sense to the lender is $1 / 24$ th, or just over 2 percent, of the anticipated loss given foreclosure. Such a policy will obviously be extremely limited in its effectiveness.

Many of the existing proposals to combat the U.S. foreclosure crisis effectively provide a federal government guarantee on the reduced balance of the loan, which artificially raises $\alpha_{1}$ to unity. ${ }^{25}$ However, this fix only reduces the maximum level of assistance from $1 / 24$ th of the anticipated loss given foreclosure to $1 / 10$ th of the loss.

The problem here is that without precisely identifying at-risk borrowers, lenders can only profitably offer a tiny amount of assistance - less than 10 percent of their anticipated loss given foreclosure - and such assistance is unlikely to reduce the likelihood of foreclosure. Policymakers are clearly aware of this problem and they have come up with several fixes. In the next section we focus on two. Both of these proposals condition assistance on the financial situation of the borrowers, but they do so in different ways.

\section{$5 \quad$ Analyzing foreclosure prevention proposals}

Loss mitigation schemes face a daunting set of constraints. The programs are typically voluntary, so they must be attractive to both borrowers and lenders. For borrowers, this means that the scheme must reduce the value of the mortgage relative to the value of the house (equation (7)). To be attractive to the lender, loss mitigation must increase expected loan recovery (so equation (9) must exceed (8)). And finally, for the policymaker, $\alpha_{1}$ should be less than $\alpha_{0}$ (the policy should lower the incidence of foreclosure).

The two most common loss mitigation schemes are modification and forbearance. Modification enacts a permanent change in the terms of the loan. Typically this involves a reduction in the interest rate, but in more extreme cases, the outstanding principal balance is reduced as well. Forbearance, on the other hand, involves a lender temporarily agreeing to accept lower payments, without changing any of the original terms of the loan. With forbearance, the borrower is still liable for the payments

\footnotetext{
${ }^{25}$ This is done, for example, in H.R. 3221, which proposes to refinance the reduced balance with an FHA-insured mortgage. H.R. 3221 refers to the American Housing Rescue and Foreclosure Prevention Act of 2008 (previously titled The 2008 Foreclosure Prevention Act). Details of this legislation can be found on the website of The Library of Congress: http://thomas.loc.gov/cgibin/query/D?c110:5:./temp/ c110mqyGOr
} 
required by the original mortgage, but the gap between the reduced and original payments is added to the outstanding balance of the loan.

The choice between modification and forbearance is typically thought of as one for the servicer of the mortgage, and not necessarily the lender or the mortgage holder. ${ }^{26}$ Many of the public policy proposals to address the foreclosure crisis employ either modification or forbearance or some combination of the two. ${ }^{27}$ As with any such taxonomy, the distinction is not as clear in practice as it is in theory.

In short, we argue below that forbearance is a much more effective tool for reducing foreclosure, because it addresses the incomplete information problem described above. Using our model of borrowers from Section 3, we show that modifications are attractive to all borrowers, regardless of whether they are in financial distress, whereas forbearance is attractive only to borrowers who are really in trouble. As a consequence, the costs of forbearance are low, which means that lenders can offer correspondingly larger benefits.

\section{$5.1 \quad$ Modification plans}

Loan modification plans are attractive to virtually all borrowers. The majority of modifications involve either reducing the interest rate or reducing the outstanding mortgage balance or both, which unambiguously increases the value of staying in the home (equation (7)). Consequently, with such a policy, one cannot assume that because a borrower asks for or accepts a modification, he or she would have defaulted without the modification. This suggests that $\alpha_{0}$ may be quite low, and, as discussed above, if this is the case, lenders can profitably offer only a tiny amount of assistanceless than 10 percent of their anticipated loss given foreclosure in our example. Such a low level of assistance is unlikely to reduce the likelihood of foreclosure. Policymakers are clearly aware of this problem and they have come up with several fixes. In this section, we focus on two proposed solutions.

The first method to identify borrowers at risk is to condition assistance on vari-

\footnotetext{
${ }^{26}$ In many MBS agreements for example, the servicer has the discretion to adopt any policy that increases the net present value of interest and principal mortgage repayments.

${ }^{27}$ For example, H.R. 3221, currently winding its way through Congress, is a modification plan, because it involves permanently reducing the outstanding balance on the mortgage. "Appreciating America," the Federal Deposit Insurance Corporation (FDIC), and Office of Thrift Supervision (OTS) plans, are basically forbearance plans in that they do not reduce the outstanding balance of the mortgage. Appreciating America is a proposal designed by Nicholas Bratsafolis, Chairman and CEO of Refinance.com. Details regarding the FDIC foreclosure prevention plan can be found on the FDIC website: http://www.fdic.gov/consumers/loans/hop/. Details regarding the OTS foreclosure prevention plan can be found on the OTS website: http://www.ots.treas.gov/docs/4/481075.pdf.
} 
ables that, in addition to negative housing equity, predict foreclosure. However, this strategy leads to a serious moral hazard problem, as most of these informational variables are under the control of the borrower, so the policy may have the perverse effect of encouraging behavior that predicts foreclosure. For example, a loss mitigation policy could condition assistance on delinquency, as borrowers who do not become delinquent on their payments never end up in foreclosure. But this requirement obviously encourages borrowers to become delinquent on their loans in order to qualify for the policy. An alternative is to condition assistance on financial ratios like the front-end, debt-to-income (DTI) ratio, the ratio of monthly mortgage payments to monthly income, or the back-end DTI ratio, the ratio of all monthly debt payments to monthly income. However, borrowers can also manipulate these ratios, the former by reducing either their reported or their actual income, and the latter by increasing their exposure to other forms of debt. Lenders and policymakers would have a very difficult time distinguishing between cases in which the borrower's DTI ratio falls because of a legitimate, unexpected income shock (such as job loss), and cases in which the borrower manipulates his or her income or debt levels in order to qualify for mitigation. Thus, conditioning mitigation on the disclosure of information controlled by the borrower, and not subject to independent verification, can lead to inefficient outcomes. ${ }^{28}$

The second fix addresses the identification problem by conditioning assistance on characteristics of the borrower prior to the introduction of the plan. For example, the issue of moral hazard could be solved by limiting assistance to borrowers who had a DTI ratio above a certain level at the time of mortgage origination, or in the period before the plan was introduced. ${ }^{29}$

\footnotetext{
${ }^{28} \mathrm{~A}$ counterargument to the moral hazard issue is that making foreclosure appear more likely in order to obtain mitigation assistance is risky because the borrower will incur other costs associated with such actions. For example, by deliberately missing a mortgage payment, a borrower will see his or her credit score fall. Given these costs, will a borrower really encourage his spouse to quit working, or quit himself, to make interest payments appear unaffordable? The potential gains in many of the outstanding proposals are so large that the answer to this question may, in fact, be yes. One example is H.R. 3221, which reduces the nominal principal balance to 90 percent of the appraised value of the home for borrowers who qualify. For example, if the current market value of the home is $\$ 175$ thousand while the nominal mortgage balance is $\$ 200$ thousand, the borrower would see his balance fall by $\$ 42$ thousand.

${ }^{29}$ For example, H.R. 3221 limits eligibility to borrowers who had a front-end DTI ratio greater than 35 percent as of March 1, 2008. Since the legislation was not even tabled, let alone enacted on March 1, 2008, a borrower would have needed extraordinary foresight to have reduced his or her income, or increased debt load in anticipation of the forthcoming legislation. So, in a sense, H.R. 3221 does solve the moral hazard problem.
} 
However, the policy fix of conditioning assistance on past information comes at an enormous cost: many at-risk borrowers will not qualify. The basic reason is that many of the borrowers who will eventually lose their homes were neither delinquent, nor in any trouble before mitigation proposals were discussed. Returning again to our past foreclosure episode, Figure 1 shows the evolution of house prices and foreclosures in the 1990s. The key point to notice in the figure is that prices had stopped falling by the beginning of 1993, remaining steady thereafter, but foreclosures remained at historically elevated levels until 1999. The reason for this is that there were many homeowners with negative equity in the 1990s, specifically, the people who bought in 1988 through 1992 . While these homeowners were not losing any more equity after 1993, they were not gaining much either. Thus, they remained vulnerable to adverse life events, like job loss, illness, and divorce, all of which create cash-flow problems. Above, we argued that foreclosures are driven by the combination of negative equity and cash-flow problems. If, in fact, the government had enacted loan-modification legislation at an equivalent point in the previous Massachusetts housing cycle, many of the borrowers who ended up in foreclosure would have been unable to qualify for any assistance because their problems emerged too late for them to qualify for assistance.

Another way to see this point is to return to our theoretical model in Section 3. Using equation (7), we argued that defaults among otherwise identical borrowers result from differences in the rate at which they discount future consumption, as measured by $r_{i}$. Borrowers with low current consumption prefer to consume more today, and thus, the lure of future payoffs from the sale of the home do not offset high current mortgage payments. We argued that borrowers facing an adverse life event are precisely those borrowers who discount the future more, and thus, are more likely to default today. Conditioning assistance on high front-end DTI ratios in the past will not necessarily identify borrowers with high discount rates today, or in the future.

There is one potentially sound reason for conditioning assistance on past information. If one of the main drivers of foreclosures is the terms of the loans, which are set at origination, then conditioning on past information may make sense. For example, there are many anecdotes that make the claim that subprime loans were unaffordable at origination, or became unaffordable after the reset of an adjustable rate. But, going forward, this is a hard story to square with the data. The peak of subprime lending in Massachusetts occurred in 2005 and 2006, so if those borrowers are still solvent now, then they have managed to have made two years of mortgage payments. In these cases it is hard to argue that the payments are now "unafford- 
able." Furthermore, we argue elsewhere [Foote, Gerardi, Goette, and Willen (2008)] that there is little evidence that the resets of adjustable rate mortgages cause systematic delinquency or foreclosure. The point is that even in this most recent housing downturn, most foreclosures result from life events, and an effective response must address current and future life events, not just past ones.

\subsection{Forbearance}

To illustrate forbearance, we start with an abstract example. We assume a population of borrowers who are identical except for their discount rates, $r_{i}$, which are observed only by the borrowers. We make the simplifying assumption in equation (7) that the house price exceeds the balance of the mortgage in the future with certainty $\left(P_{2}>M_{2}\right)$. The lender offers the borrower a payment reduction now, of amount $a$, with the provision that the borrower repay $a(1+\hat{r})$ at maturity. The borrower will choose to accept this offer if the value of the house net of the mortgage rises with the forbearance. In other words,

$$
V_{1}^{H}-V_{1}^{M}=\left(\text { rent }_{1}-\text { mpay }_{1}+a\right)+\frac{1}{1+r_{i}} \cdot\left[P_{2}-M_{2}-a(1+\hat{r})\right]
$$

has to exceed,

$$
V_{1}^{H}-V_{1}^{M}=\left(\text { rent }_{1}-\text { mpay }_{1}\right)+\frac{1}{1+r_{i}} \cdot\left(P_{2}-M_{2}\right),
$$

which simplifies to the condition that

$$
a>\frac{(1+\hat{r})}{\left(1+r_{i}\right)} a
$$

or

$$
r_{i}>\hat{r}
$$

In words, this equation says that if the borrower discounts the future by more than $\hat{r}$, then he or she will prefer forbearance. Note that, unlike principal reduction or decreasing the contract interest rate, forbearance is not attractive to everyone-borrowers with $r_{i}<\hat{r}$ will choose to not participate.

From equation (10), we know that lenders want only borrowers who are in danger of foreclosure to choose forbearance. Thus, as policymakers we must answer the question of who will default in the absence of forbearance (our target group)? As discussed above, borrowers for whom $V_{1}^{H}-V_{1}^{M}$ falls below zero have a financial incentive to walk away from their mortgage. This implies that a borrower will default if:

$$
\frac{\left(P_{2}-M_{2}\right)}{\left(\text { mpay }_{1}-\text { rent }_{1}\right)}-1<r_{i} \text {. }
$$


It is easy to see that if we set $\hat{r}$ equal to the left-hand side of (15), then condition (14) will only hold for borrowers who are in danger of foreclosure.

Now we turn our attention to the lender. Using our notation from Section 4, the lender compares the expected recovery with and without forbearance. Without forbearance, the expected recovery is:

$$
E[\text { Recovery }]=\alpha_{0}\left(p_{H}-\lambda\right)+\left(1-\alpha_{0}\right) m
$$

Under a forbearance policy, the lender does not reduce the principal balance. Instead, the lender accepts a lower current mortgage payment in exchange for increased future repayment. Assuming that the lender's forbearance policy reduces the current mortgage payment by $a$, and assuming that some borrowers may still end up in foreclosure, the expected recovery is

$$
E\left[\text { Recover } y_{F}\right]=\alpha_{1}\left(p_{H}-\lambda\right)+\left(1-\alpha_{1}\right)(m+a \cdot(1+\hat{r}))-a
$$

Forbearance is optimal from the lender's perspective if (17) exceeds (16) or if:

$$
a<\frac{\alpha_{0}-\alpha_{1}}{\alpha_{1}-\left(1-\alpha_{1}\right) \cdot \hat{r}}\left[m-\left(p_{h}-\lambda\right)\right]
$$

To see how this works, set $\hat{r}=0$, and assume that the incentive compatibility condition assures us that $\alpha_{0}=1$. Then equation (18) becomes:

$$
a<\frac{1-\alpha_{1}}{\alpha_{1}}\left[m-\left(p_{h}-\lambda\right)\right]
$$

If $\alpha_{1}=0.5$, in other words, if forbearance lowers the probability of default to 50 percent, then the lender can afford to lend the borrower its anticipated loss from foreclosure. In this case, the lender is basically going double or nothing. If the borrower repays, the lender recoups everything, but if the borrower defaults, it loses twice as much. Thus, in terms of expectations, under these conditions the outcome of forbearance for the lender is exactly the same as the outcome from foreclosure.

\subsection{Expanded forbearance}

Several recent public policy proposals offer borrowers an option that basically amounts to forbearance. The plans differ significantly in the details, so in this section we will focus on a stylized plan, which captures the basic features of all of these plans. ${ }^{30}$ What they all share is the basic forbearance theme of lowered payments without

\footnotetext{
${ }^{30}$ The proposals that we are referring to include the OTS plan, the FDIC plan, and the private "Appreciating America" plan from Refinance.com.
} 
reduced overall liability for borrowers. But, all of the plans go well beyond what a servicer can feasibly offer by itself. First, the federal government, through the FHA, insures a significant portion of the original mortgage, capping potential losses in the event of default, and thus limiting the downside risk of the original mortgage lender. Second, the plans offer long-term forbearance, as much as five years, as compared to a maximum of one year typically offered by servicers. These additions to forbearance may be appealing from a public policy perspective because these features increase the attractiveness of a forbearance policy to both lenders and borrowers. ${ }^{31}$ Lenders have a large incentive to adopt such a policy since it places a lower bound on financial losses from foreclosure, while the longer time horizon of reduced mortgage payments appeals to borrowers, as it provides a greater amount of time to solve adverse transitory income events such as job loss.

For this discussion, we will assume that the borrower has only a single mortgage and is in a position of negative equity. The first step in our fictitious plan provides the borrower with a new FHA-insured loan for an amount substantially below the outstanding balance of the current mortgage. The borrower promises to repay the difference between the balance of the current mortgage and the balance of the new FHA-insured mortgage at some point in the future, or in the event of sale or subsequent refinance. The key is that the borrower makes no periodic payments on this difference until the loan matures. However, interest does accrue on the difference. Essentially the borrower finances the balance of the original loan with a zero coupon bond payable at sale or in the event of a refinance, or at some fixed point in the future stipulated by the policy.

To see that this policy amounts to forbearance, we can express this in the language of the model in Section 4. Assume that the new mortgage has value $(m-a)$ to the lender. The zero coupon bond means that the borrower promises to repay the original lender $a(1+\hat{r})$ at maturity. There are two possible outcomes: with probability $\alpha_{1}$ the borrower defaults on the loan to the original lender, in which case we assume that original lender receives only the proceeds from the refinance $(m-a)$; with probability $\left(1-\alpha_{1}\right)$ the borrower makes good on the promise to the original lender and repays $a(1+\hat{r})$. Thus, the lender's expected recovery is

$$
\alpha_{1} \cdot(m-a)+\left(1-\alpha_{1}\right) \cdot(m+\hat{r} \cdot a) .
$$

In other words, with probability $\alpha_{1}$ the lender loses $a$ because the borrower cannot repay the loan, but with probability $\left(1-\alpha_{1}\right)$ the lender makes $\hat{r} a$ because the borrower

\footnotetext{
${ }^{31}$ On the other hand, such policies place more risk on the federal government, and thus the taxpaying public.
} 
repays the balance of the loan with interest. The gain for the lender from adopting this loss mitigation strategy is:

$$
\left(1-\alpha_{1}\right) \cdot(\hat{r} \cdot a)-\alpha_{1} \cdot a+\alpha_{0}\left[m-\left(p_{h}-\lambda\right)\right] .
$$

For simplicity, assume that $\hat{r}=0$, then equation (19) implies the following condition for successful loss mitigation:

$$
a<\frac{\alpha_{0}}{\alpha_{1}}\left[m-\left(p_{h}-\lambda\right)\right]
$$

How does expanded forbearance (equation (20)) compare with regular forbearance (equation (18)). The key difference here is that the refinance assures the lender that if the borrower defaults after forbearance, it will only lose $a$ and not $m-\left(p_{h}-\lambda\right)$, and so the $\alpha_{1}$ in the numerator of the fraction disappears. Practically, this means the lender can afford to be even more generous with forbearance. In our above example, if $\alpha_{0}=1$ and $\alpha_{1}=0.5$, then the lender was effectively going double or nothing by offering a temporary reduction of $a$. Now, the temporary reduction in the monthly mortgage payment is the most the lender can expect to lose.

\section{Conclusions}

The initial key conclusions of this paper can be summed up in two statements which, at first blush, appear contradictory. The first conclusion is that most borrowers who lose their homes have negative equity. The second is that most borrowers with negative equity will not lose their homes to foreclosure. The first statement reflects the necessity of negative equity for foreclosure-borrowers with positive housing equity will sell if they need to move. The second statement addresses the fact that the default decision involves weighing the payments on the mortgage against the income, imputed or actual, that accrues from retaining ownership of the house.

The second important set of conclusions follows from the first, by illustrating that policy responses need not, and probably cannot, address the negative equity problem directly. Instead, these policies should focus on lowering current mortgage payments in order to make default less attractive to the borrower. Forbearance programs that allow borrowers to delay, but not to avoid eventually repaying the mortgage in full can help at-risk borrowers without generating serious moral hazard problems, involving assistance, funded at the public's expense, to those who do not need it.

Our model of the default decision in Section 3 emphasizes intuition over realism. In future work, we hope to build a model that incorporates a richer, dynamic environment more consistent with the choices and decisions borrowers actually face. 


\section{Appendix: Duration Model Details}

This appendix provides some of the technical details of the duration model of homeownership termination employed in Section 2.2.2. For further details, we direct the reader to Section 3 in GSW.

Formally, the hazard function for the $r$ th action is given by

$$
\lambda_{i}^{r}(t)=\lim _{\Delta t \rightarrow 0} \frac{P\left(t<T_{i}^{r}<t+\Delta t \mid T_{i}^{r} \geq t\right)}{\Delta t},
$$

where borrower $i$ can terminate the ownership by selling the home, $r=S$, or defaulting on the loan payment and inducing foreclosure, $r=F$.

The proportional hazard specification assumes that there is a hazard common to all homeownership experiences, $i \in N$ for foreclosure $\lambda_{0}^{F}(t)$, and for sale $\lambda_{0}^{S}(t)$, and that the covariates have proportional effects on these common hazards. These hazards are referred to as the baseline hazards for foreclosure and sale, respectively, and are given by

$$
\lambda^{r}\left(t \mid X_{i}(t)\right)=\lambda_{0}^{r}(t) \exp \left(X_{i}(t)^{\prime} \cdot \beta^{r}\right), \quad r \in\{S, F\}
$$

where $r$ indexes the type of termination, foreclosure, or sale.

We restrict the shape of the baseline hazard to a third-degree polynomial in the age of the ownership, such that $\lambda_{0}^{r}(t)=\exp \left(\alpha_{0}+\alpha_{1, i} t+\alpha_{2, i} t^{2}+\alpha_{3, i} t^{3}\right){ }^{32}$ Since we do not observe the data continuously, but only in discrete, quarterly intervals, we must account for this when forming the likelihood function. This involves a slight modification of the hazard formulas. ${ }^{33}$ We estimate the model using maximum-likelihood techniques.

\footnotetext{
${ }^{32}$ Assuming a higher-order polynomial does not significantly affect the estimation results.

${ }^{33}$ For further details regarding the discreteness correction and the formation of the likelihood function, see GSW, or Meyer (1995).
} 


\section{References}

[1] Chomsisengphet, S., and A. Pennington-Cross. 2006. "The Evolution of the Subprime Mortgage Market." Federal Reserve Bank of St. Louis Review 88(1): 31-56.

[2] Foote, C., Gerardi, K., Goette, L., and P. Willen. 2008. "Subprime Facts: What (We Think) We Know About the Subprime Crisis and What We Don't" Federal Reserve Bank of Boston Public Policy Discussion Paper No. 08-2.

[3] Gerardi, K., Shapiro, A., and P. Willen. 2007. "Subprime Outcomes: Risky Mortgages, Homeownership Experiences, and Foreclosure." Federal Reserve Bank of Boston Working Paper No. 07-15.

[4] Kau J., D. Keenan, and T. Kim. 1994. "Default Probabilities for Mortgages." Journal of Urban Economics 35: 278-296.

[5] Meyer, B. 1995. "Semiparametric Estimation of Hazard Models." MIT working paper.

[6] Pennington-Cross, A. 2002. "Subprime Lending in the Primary and Secondary Markets." Journal of Housing Research 13(1): 31-50.

[7] Quercia, R., and M. Stegman. 1992. "Residential Mortgage Default: A Review of the Literature." Journal of Housing Research 3(2): 341-379.

[8] Stanton, R. 1995. "Rational Prepayment and the Valuation of Mortgage-Backed Securities." Review of Financial Studies 8(3): 677-708.

[9] Vandell K. 1995. "How Ruthless is Mortgage Default? A Review and Synthesis of the Evidence." Journal of Housing Research 6(2): 245-264. 
Table 1: Negative Equity Borrowers and Subsequent Foreclosures in Massachusetts

\begin{tabular}{c|c|c|c|c}
\hline \hline & $1991: \mathrm{Q} 4$ & \multicolumn{3}{|c}{$2007: \mathrm{Q} 4$} \\
\hline \# Negative Equity Borrowers & 100,288 & \multicolumn{3}{|c}{94,608} \\
\hline \# Future Foreclosures & & Scenario 1 & Scenario 2 & Scenario 3 \\
\cline { 3 - 5 } Quarter 1 & 618 & 458 & 470 & 475 \\
Quarter 2 & 542 & 494 & 520 & 531 \\
Quarter 3 & 610 & 525 & 567 & 584 \\
Quarter 4 & 606 & 549 & 608 & 632 \\
Quarter 5 & 606 & 567 & 642 & 645 \\
Quarter 6 & 535 & 578 & 669 & 649 \\
Quarter 7 & 490 & 582 & 687 & 645 \\
Quarter 8 & 516 & 579 & 698 & 635 \\
Quarter 9 & 490 & 571 & 700 & 610 \\
Quarter 10 & 543 & 557 & 696 & 580 \\
Quarter 11 & 480 & 539 & 685 & 548 \\
Quarter 12 & 417 & 518 & 669 & 515 \\
\hline Total & 6,453 & 6,516 & 7,613 & 7,049 \\
\hline \hline of Negative Equity Borrowers & $\mathbf{6 . 4}$ & $\mathbf{6 . 9}$ & $\mathbf{8 . 0}$ & $\mathbf{7 . 5}$ \\
\hline \hline
\end{tabular}

Note: Scenario 1 corresponds to flat house prices over three years (0 growth). Scenario 2 corresponds to a uniform 10 percent decline in house prices over 3 years. Scenario 3 corresponds to a 5 percent decline in the first year, followed by a 1 percent and 3 percent increase in the second and third years, respectively. 
Table 2: Summary Statistics for Negative Equity Borrowers in Massachusetts

\begin{tabular}{|c|c|c|c|c|}
\hline & \multicolumn{2}{|c|}{ 2007:Q4 } & \multicolumn{2}{|c|}{ 1991:Q4 } \\
\hline & $\begin{array}{c}\text { Negative equity } \\
(\%)\end{array}$ & $\begin{array}{c}\text { All borrowers } \\
(\%)\end{array}$ & $\begin{array}{c}\text { Negative equity } \\
(\%)\end{array}$ & $\begin{array}{c}\text { All borrowers } \\
(\%)\end{array}$ \\
\hline \multicolumn{5}{|l|}{ Property Type } \\
\hline Single-family & 57.4 & 70.8 & 58.7 & 67 \\
\hline Multi-family & 17.1 & 10.6 & 14.5 & 10.3 \\
\hline Condo & 25.5 & 18.6 & 26.9 & 22.7 \\
\hline \multicolumn{5}{|l|}{ Income Level (Zip code) } \\
\hline Low & 1.1 & 0.6 & 0.7 & 0.6 \\
\hline Moderate & 31.4 & 18.2 & 27.4 & 18.6 \\
\hline Middle/High & 67.5 & 81.3 & 71.9 & 80.8 \\
\hline \multicolumn{5}{|l|}{ Subprime Purchase } \\
\hline & 18.7 & 4.5 & 0.0 & 0.0 \\
\hline Minority \% (Zip code) & & & & \\
\hline Average & 22.2 & 15.0 & 20.6 & 15.4 \\
\hline
\end{tabular}

Note: Information regarding average income and the percentage of minority households in the zip code is obtained from the 2000 U.S. Census. Low-income zip codes are defined to be zip codes in which the median household income is less-than-or-equal to 50 percent percent of the state median, while moderate-income zip codes have median income values between 50 percent and 80 percent of the state median. Information regarding property types is obtained from the Warren Group, and indicators of mortgages originated by subprime lenders are constructed using the HUD subprime lender list. 
Table 3: Estimation Results from Duration Model

\begin{tabular}{|c|c|c|c|c|}
\hline & \multicolumn{2}{|c|}{ Default } & \multicolumn{2}{|c|}{ Sale } \\
\hline & Coef & Std. Err. & Coef & Std. Err. \\
\hline equity & -3.08 & 0.11 & -0.43 & 0.02 \\
\hline negative equity indicator & 0.08 & 0.06 & -0.04 & .20 \\
\hline libor (6-month) & 0.05 & 0.01 & -0.08 & $2.91 \mathrm{e}^{-03}$ \\
\hline unemployment rate & 0.05 & $6.07 \mathrm{e}^{-03}$ & -0.07 & $2.99 \mathrm{e}^{-03}$ \\
\hline$\%$ minority (2000 zip-code) & $7.85 \mathrm{e}^{-03}$ & $1.08 \mathrm{e}^{-03}$ & $3.32 \mathrm{e}^{-03}$ & $3.23 \mathrm{e}^{-04}$ \\
\hline median income (2000 zip-code) & $-1.60 \mathrm{e}^{-05}$ & $1.82 \mathrm{e}^{-06}$ & $-1.65 \mathrm{e}^{-06}$ & $3.06 \mathrm{e}^{-07}$ \\
\hline condo indicator & 0.36 & 0.05 & 0.51 & 0.01 \\
\hline multi-family property indicator & 0.46 & 0.05 & 0.04 & 0.02 \\
\hline subprime purchase indicator & 2.21 & 0.07 & 0.41 & 0.03 \\
\hline \# observations & \multicolumn{2}{|c|}{$3,375,320$} & \multicolumn{2}{|c|}{$3,375,320$} \\
\hline Log Likelihood & \multicolumn{2}{|c|}{$-260,393$} & \multicolumn{2}{|c|}{$-260,393$} \\
\hline
\end{tabular}

Note: Baseline hazard is assumed to be a third-order polynomial in the age of the ownership. Parameter estimates for age polynomial are not shown for brevity, but are available upon request. 
Table 4: Standardized Elasticities

\begin{tabular}{l|c|c|c}
\hline \hline & & Default & Sale \\
\cline { 3 - 4 } & $(+/-)$ std. dev. & \% change hazard & \% change hazard \\
\hline equity & $(-) 0.38$ & 222 & -15.1 \\
negative equity indicator & $\cdot$ & 8.5 & -32.9 \\
libor (6-month) & $(+) 1.85$ & 9.2 & -14.5 \\
unemployment rate & $(+) 2.06$ & 10.3 & -13.6 \\
\% minority (2000 zip-code) & $(+) 19.58$ & 16.6 & 6.7 \\
median income (2000 zip-code) & $(-) \$ 24,493$ & 48.0 & -4.0 \\
multi-family indicator & $\cdot$ & 58.0 & 4.3 \\
condo indicator & $\cdot$ & 43.4 & 66.3 \\
subprime purchase indicator & $\cdot$ & 813 & 50.4 \\
\hline \hline
\end{tabular}

\begin{tabular}{l|l|c|c}
\hline \hline & $\begin{array}{l}\Delta x(+/- \text { one std. dev. } \\
0-1 \text { change for dummy variables })\end{array}$ & Default & Sale \\
\hline \multirow{2}{*}{$(\bar{x})(\%)$} & & $\mathbf{0 . 0 4 9}$ & $\mathbf{1 . 6 1 9}$ \\
& & & \\
\hline$\hat{\lambda}(\bar{x}+\Delta x)(\%)$ & & & \\
& equity (-) & 0.162 & 0.84 \\
& libor $(+)$ & 0.054 & 1.384 \\
& unemployment rate $(+)$ & 0.054 & 1.398 \\
& minority \% zip-code $(+)$ & 0.057 & 1.728 \\
& median income zip-code $(-)$ & 0.073 & 1.555 \\
& multi-family & 0.077 & 1.689 \\
& condo & 0.070 & 2.692 \\
& subprime purchase & 0.447 & 2.435 \\
\cline { 2 - 4 } & equity + subprime & 1.479 & 1.266 \\
\hline
\end{tabular}

Note: Continuous explanatory variables are increased/decreased by one standard deviation while dichotomous explanatory variables are changed from zero to one. 
Table 5: Massachusetts Borrowers and Estimated Foreclosure Predictions

\begin{tabular}{l|c|c|c}
\hline \hline & \multicolumn{3}{|c}{ 2007:Q4 } \\
\hline \# Borrowers & \multicolumn{3}{|c}{965,330} \\
\hline \# Predicted Foreclosures & Scenario 1 & Scenario 2 & Scenario 3 \\
\cline { 2 - 4 } $2008 \mathrm{q} 1$ & 848 & 872 & 882 \\
$2008 \mathrm{q} 2$ & 896 & 947 & 968 \\
$2008 \mathrm{q} 3$ & 936 & 1017 & 1050 \\
$2008 \mathrm{q} 4$ & 967 & 1079 & 1126 \\
$2009 \mathrm{q} 1$ & 989 & 1132 & 1139 \\
$2009 \mathrm{q} 2$ & 1002 & 1176 & 1141 \\
$2009 \mathrm{q} 3$ & 1004 & 1209 & 1132 \\
$2009 \mathrm{q} 4$ & 998 & 1231 & 1113 \\
$2010 \mathrm{q} 1$ & 983 & 1242 & 1070 \\
$2010 \mathrm{q} 2$ & 962 & 1243 & 1021 \\
$2010 \mathrm{q} 3$ & 934 & 1235 & 967 \\
$2010 \mathrm{q} 4$ & 901 & 1218 & 911 \\
\hline Total & 11,419 & 13,601 & 12,520 \\
\hline \% of All Borrowers & $\mathbf{1 . 2 \%}$ & $\mathbf{1 . 4 \%}$ & $\mathbf{1 . 3 \%}$ \\
\hline \hline
\end{tabular}

Note: Scenario 1 corresponds to flat house prices over three years (0 growth). Scenario 2 corresponds to a uniform 10 percent decline in house prices over 3 years. Scenario 3 corresponds to a 5 percent decline in the first year, followed by a 1 percent and 3 percent increase in the second and third years, respectively. 
Table 6: Massachusetts Borrowers with Negative Equity and Subsequent Foreclosures under Principal Reduction

\begin{tabular}{l|c|c|c}
\hline \hline & \multicolumn{3}{|c}{$2007: \mathrm{Q} 4$} \\
\hline \# Negative Equity Borrowers & \multicolumn{3}{|c}{94,608} \\
\hline \# Predicted Foreclosures & Scenario 1 & Scenario 2 & Scenario 3 \\
\cline { 2 - 4 } $2008 q 1$ & 304 & 338 & 342 \\
$2008 q 2$ & 328 & 377 & 385 \\
$2008 q 3$ & 349 & 415 & 428 \\
$2008 q 4$ & 366 & 450 & 468 \\
$2009 q 1$ & 379 & 481 & 483 \\
$2009 q 2$ & 387 & 507 & 492 \\
$2009 q 3$ & 391 & 528 & 495 \\
$2009 q 4$ & 391 & 543 & 493 \\
$2010 q 1$ & 386 & 552 & 479 \\
$2010 q 2$ & 378 & 555 & 461 \\
$2010 q 3$ & 367 & 553 & 440 \\
$2010 q 4$ & 353 & 547 & 417 \\
\hline Total & 4,379 & 5,845 & 5,384 \\
\hline \% of Negative Equity Borrowers & $\mathbf{4 . 6}$ & $\mathbf{6 . 2}$ & $\mathbf{5 . 7}$ \\
\hline \hline
\end{tabular}

Note: Scenario 1 corresponds to flat house prices over three years ( 0 growth). Scenario 2 corresponds to a uniform 10 percent decline in house prices over 3 years. Scenario 3 corresponds to a 5 percent decline in the first year, followed by a 1 percent and 3 percent increase in the second and third years, respectively. 
Figure 1: Massachusetts House Prices and Foreclosure Rates, January 1990 to December 2007

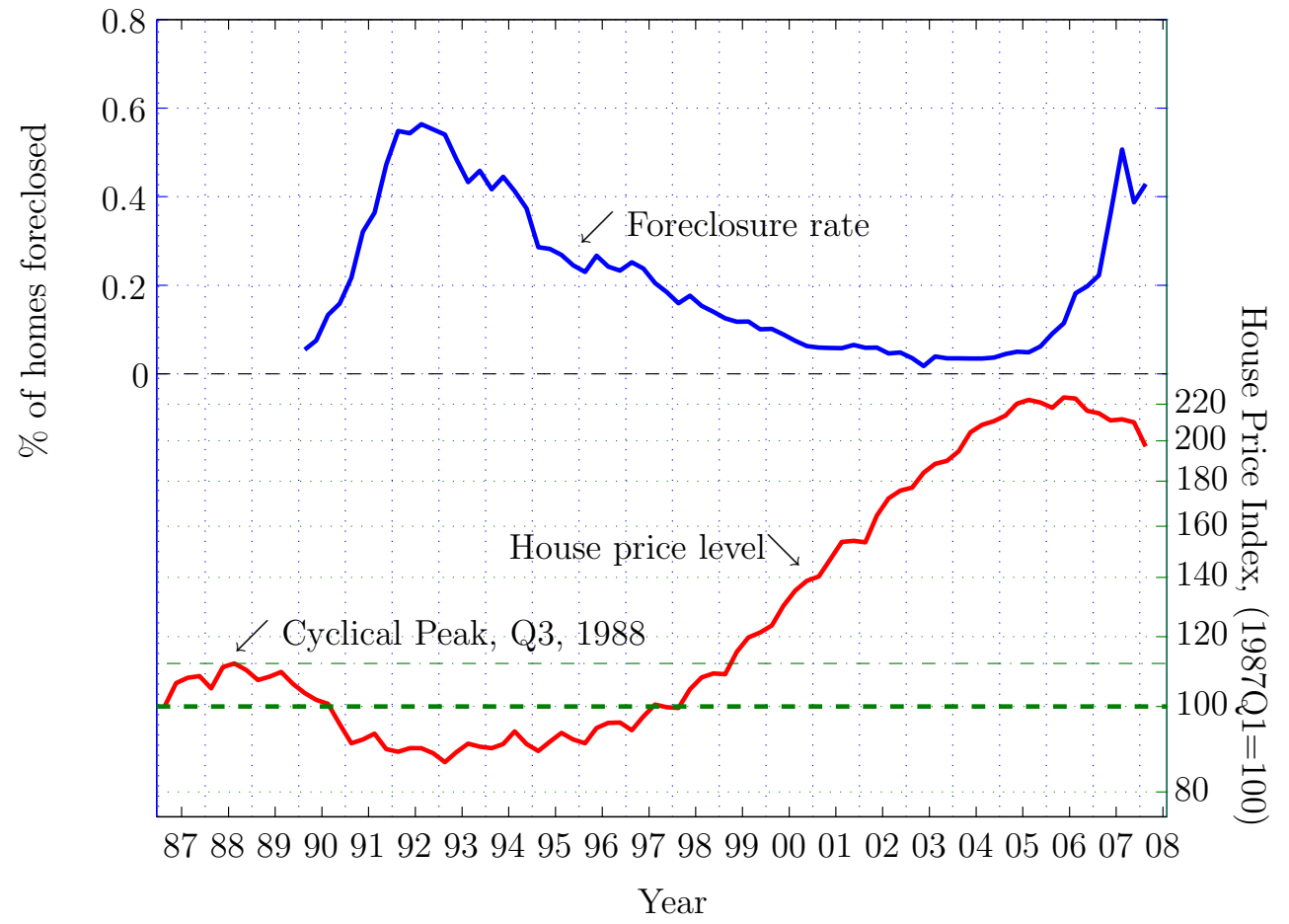

Note: The foreclosure rate is calculated at a quarterly frequency. The numerator is the total number of foreclosures in MA in a given quarter, and is obtained directly from the Warren Group data. The denominator is the number of residential parcels in a given year, where a parcel is defined as a real unit of property used for the assessment of property taxes, and a typical parcel consists of a plot of land defined by a deed and any buildings located on the land. Information on parcel counts is obtained from the Massachusetts Department of Revenue. Finally, house prices are calculated using the Case-Shiller weighted, repeat-sales methodology using data from the Warren Group. 
Figure 2: Future House Price Scenarios for Massachusetts
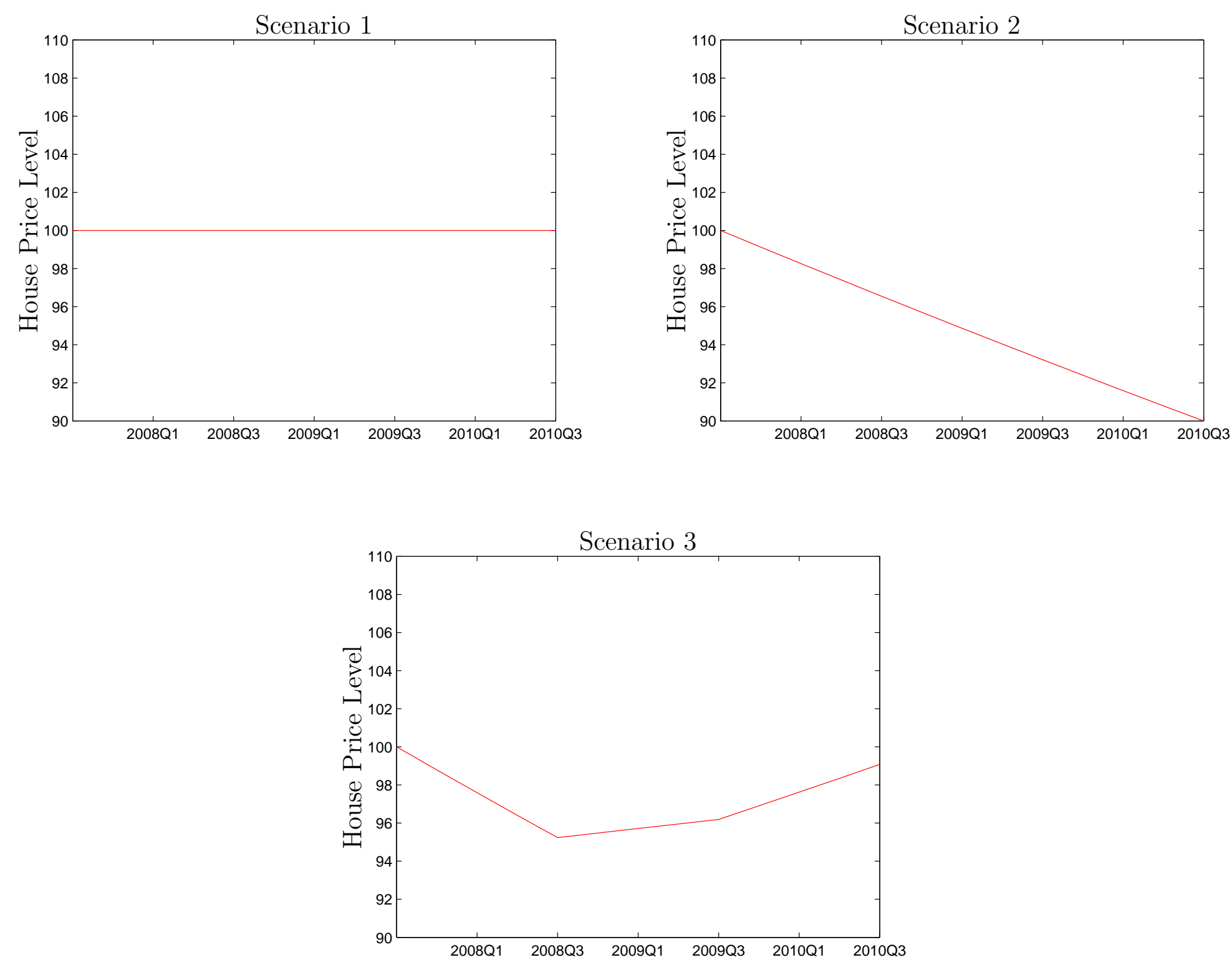